[Radiocarbon, Vol. 12, No. 1, 1970, P. 161-180]

\title{
UNIVERSITY OF MICHIGAN RADIOCARBON DATES XIII
}

\author{
H. R. CRANE and JAMES B. GRIFFIN
}

The University of Michigan, Ann Arbor, Michigan

The following is a list of dates obtained since the compilation of List XII. The method is essentially the same as described in that list. Two $\mathrm{CO}_{2}-\mathrm{CS}_{2}$ Geiger counter systems were used. Equipment and counting techniques have been described elsewhere (Crane, 1961). Dates and estimates of error in this list follow the practice recommended by the International Radiocarbon Dating Conferences of 1962 and 1965, in that (a) dates are computed on the basis of the Libby half-life, $5570 \mathrm{yr}$, (b) A.D. 1950 is used as the zero of the age scale, and (c) the errors quoted are the standard deviations obtained from the numbers of counts only. In Michigan date lists up to and including VII, we quoted errors at least twice as great as the statistical errors of counting, to take account of other errors in the over-all process.

We wish to acknowledge the help of Patricia Dahlstrom in preparing chemical samples and John D. Speth and Roberta L. Pennypacker in preparing the descriptions.

\section{GEOLOGIC SAMPLES}

\section{Green Point site series, Michigan}

Unburned twigs and wood fragments from Green Point site $\left(23^{\circ} \mathrm{N}\right.$ Lat, $83^{\circ} 59^{\prime} \mathrm{W}$ Long), S $1 / 2$ NE $1 / 4$ Sec. 3, T11N, R4E, Saginaw Co., Michigan. Transgression of lake which sample represents presumed to be rise to Lake Nipissing. Samples date series of pollen samples and macro-vegetation samples now being analyzed by W. S. Benninghoff. Study should shed light on paleoecology of area during late Archaic. Coll. 1964 by H. T. Wright; subm. by W. S. Benninghoff, Dept. of Bot., Univ. of Michigan, and H. T. Wright, Mus. of Anthropol., Univ. of Michigan.

\section{M-1633. Green Point site}

$5050 \pm 170$

Sample point Locus 563 E $596,+581.2 \mathrm{ft}$. Top of swamp sediment column and top of pollen column. Dates rise of water over $+582 \mathrm{ft}$ on some unknown transgression of lake.

\section{M-1634. Green Point site}

$4250 \pm 150$ 2300 B.c.

Sample point Locus 563 E $596,+579.9 \mathrm{ft}$ near bottom of pollen column. Dates rise of water above $580 \mathrm{ft}$.

General Comment (J.B.G.): pollen analysis not complete and transposition of dates is not understood.

M-1885. Welwitschia hainesii, South Africa

Wood, part of stem of Welwitschia bainesii plant found near Swakop R. (221/20 S Lat, $12^{\circ}$ E Long), SW Africa (Tijmens, 1965, 1966). Coll. 
1966 by H. Maelder; subm. by W. J. Tijmens, Univ. of Stellenbosch, S. Africa. Comment (W.J.T.): knowledge of age of plant aids study of Welwitschias of Namib Desert.

\section{Pellston Plain series, Michigan}

Wood and peat samples from bog $2 \mathrm{mi} \mathrm{S}$ of Pellston $\left(45^{\circ} 32^{\prime} \mathrm{N}\right.$ Lat, $84^{\circ} 47^{\prime} \mathrm{W}$ Long), Emmet Co., Michigan. Bog is on kame surface of Valders outwash sands at E margin of Pellston Hills. Alt. of bog ca. 695 $\mathrm{ft}$, and Maple R. $1 \mathrm{mi} \mathrm{E}$ is at ca. $640 \mathrm{ft}$. Organic sediments are ca. $1 \mathrm{~m}$ thick, comprising fibrous peat, amorphous peat with wood fragments, lacustrine ooze, and sandy peat grading into coarse sand. Charcoal layers, indicating fires, occur at $4 \mathrm{~cm}, 25 \mathrm{~cm}$, and $30 \mathrm{~cm}$. Charcoal is dispersed in peat at depths of $45 \mathrm{~cm}$ and $63 \mathrm{~cm}$. Coll. 1966 and subm. by T. W. Hushen and W. S. Benninghoff, Univ. of Michigan.

\section{M-1946. Pellston Plain, $32 \mathrm{~cm}$ deep \\ $2160 \pm 140$ \\ 210 B.C.} $30 \mathrm{~cm}$.

Conifer wood, $32 \mathrm{~cm}$ deep, immediately below charcoal layer at

\section{M-1947. Pellston Plain, $43 \mathrm{~cm}$ deep}

$2810 \pm 150$

Conifer wood from $43 \mathrm{~cm}$ deep, taken from fine-grained decayed peat that contained abundant small pieces of wood and lay immediately above $45 \mathrm{~cm}$ charcoal level.

\section{M-1948. Pellston Plain, $87 \mathrm{~cm}$ deep}

$4050 \pm 180$ sand.

Sedge-moss peat from $87 \mathrm{~cm}$ deep, immediately above basal organic

General Comment (W.S.B.): dates demonstrate that this peat originated a little more than 4000 yr B.P., and that most recent natural change in forest composition began ca. 3000 yr B.P. with invasion of hemlock and birch (one or several species) which was completed ca. 2000 yr B.P. Peat stratigraphy indicates charcoal layers from severe forest fires at 2 intervals soon after 2000 B.P. and again very near surface and representing widespread timber cutting within last $100 \mathrm{yr}$. Pollen diagram prepared by T. W. Hushen shows invasion of Ericaceae ca. 3000 B.P. in small amounts but becoming very significant at same time as strong rise in Chenopod-Amaranth and composite pollen during post-lumbering phase of past century. A manuscript is being prepared for publication by $\mathrm{T}$. W. Hushen and W. S. Benninghoff.

\section{M-1972. Lake Michigan, Chippewa Stage, Michigan 5620 в.c.}

Shells from lake bottom at elev. of Chippewa low stage $\left(44^{\circ} 00^{\prime} \mathrm{N}\right.$ Lat, $87^{\circ} 14^{\prime} \mathrm{W}$ Long). Sample from shell and sand zone ca. $3 \mathrm{~cm}$ thick overlain by ca. $10 \mathrm{~cm}$ fine lake clay at present depth $350 \mathrm{ft}$. Should date Chippewa low stage or its maximum low level ca. 7500 to 9500 B.P. 
(Hough, 1955). Coll. 1966 and subm. by J. L. Hough, Univ. of Michigan. Comment (J.L.H.): $3000 \mathrm{yr}$ too young in view of M-1996 (see below).

\section{M-1996. Straits of Mackinac, Michigan}

Conifer wood, possibly spruce, from Straits of Mackinac $\left(45^{\circ} 49^{\prime} 50^{\prime \prime}\right.$ $\mathrm{N}$ Lat, $84^{\circ} 43^{\prime} 50^{\prime \prime} \mathrm{W}$ Long), Michigan. Sample rooted in $120 \mathrm{ft}$ water under Strait 150 yds WSW of S bridge tower. Whole forest drowned in place by rising waters of Lakes Michigan and Huron to Nipissing level. Coll. 1967 by L. H. Somers; subm. by J. L. Hough. Comment (J.L.H.): date provides point in age and elev. that fills important gap in lake level curves.

\section{ARCHAEOLOGIC SAMPLES}

\section{Upper Mississippi Valley and Great Lakes}

\section{New Castle site series, Indiana}

Charcoal from New Castle site $\left(39^{\circ} 57^{\prime} \mathrm{N}\right.$ Lat, $85^{\circ} 21^{\prime} \mathrm{W}$ Long), Indiana. Possibly Adena plain pottery assoc. in ash pit. Samples located in Mound 4 (Swartz, 1966). Coll. 1965 and 1966 by D. R. Middleton and W. B. Koch; subm. by B. K. Swartz Jr., Dept. of Sociol. and Anthropol., Ball State Univ.

\section{M-1851. New Castle site, Mound 4}

Charcoal from $\mathrm{E}$ side of mound.

\section{M-1852. New Castle site, Mound 4}

$1910 \pm 140$ A.D. 40

$$
1940 \pm 160
$$

A.D. 10

Charcoal from Mound 4 (BSU-8F-9-12), Unit $9 \mathrm{~W}-1 \mathrm{~N}$, ash pit 0 to $10 \mathrm{in.} \mathrm{W}$ of $\mathrm{E}$ wall at $74 \mathrm{in.}$ depth.

General Comment (B.K.S.): both lobes of Mound 4 were constructed at same time. Ceremonial complex is Hopewellian. Sample M-1852 dates New Castle Incised Adena pottery. Thirty yr span suggests solid dates.

\section{M-1891. Backland Mound Group, Michigan}

$$
\begin{array}{r}
610 \\
\text { A.D. } 1340
\end{array}
$$

Left femur, distal and proximal portions destroyed from Burial 2, mature male from Backland Mound Group (20 MN 2) $\left(45^{\circ} 39^{\prime} \mathrm{N}\right.$ Lat, $87^{\circ} 50^{\prime} \mathrm{W}$ Long), SW $1 / 4$ of NW $1 / 4$, Sec. 6, T35N, R28W, Menominee Co., Michigan. Submound floor burial of 7 individuals in pit. Bottom est. $2.1 \mathrm{ft}$ below top of mound (N60 E10). Assoc. with Oneota-like shelltempered ceramics and grit-tempered ceramics with Oneota-like vessel shape and late Manitoba focus (Sturgeon Falls Punctate:Alexander Punctate) decorative motif. Should date ca. A.D. 1400. Coll. 1956 by A. C. Spaulding; subm. by D. S. Brose, Mus. of Anthropol., Univ. of Michigan. Comment (D.S.B.): date is reasonable. 


\section{Moceasin Bluff series, Michigan}

Wood from Moccasin Bluff site (41 $51^{\prime} \mathrm{N}$ Lat, $86^{\circ} 22^{\prime} \mathrm{W}$ Long), Berrien Co., Michigan. Coll. 1948 by Hale Smith; subm. by Robert Bettarel, Univ. of Michigan.

\section{M-1935. Moccasin Bluff site}

Carya ovata, exterior of $\log 6$ to 8 in. diam., Pit 21, Level 6 . Should date pottery with notched applique strip around rim $1 \mathrm{~cm}$ below lip. Comment (R.B.): dates final occupation of site.

\section{M-1936. Moccasin Bluff site}

$$
360 \pm 100
$$

Quercus bicolor, interior of $\log$ in 4 in. diam., Pit 91, Level 4, Trench C. Comment (R.B.): should date Oneota occupation or influence.

\section{M-1937. Moccasin Bluff site}

$$
890 \pm 110
$$

Quercus bicolor from earth oven, exterior of $\log$ not over 6 in. diam., worm eaten, dead before use. Pit 54, Level 3. Should date late Spring Creek type assoc. with collared and castellated shell-tempered Woodland body sherd. Comment (R.B.): date identifies occupation of Late Woodland group.

\section{M-1938. Moccasin Bluff site}

\section{A.D. 1090}

$860 \pm 110$

Celtis occidentalis, $\log 10$ in. diam.; Quercus bicolor; Castenea dentato, outside of $\log 8$ in. diam.; Acer, 3 in. from center of $\log$. Pit 86 , Trench C, Levels 5, 6, and 7. Comment (R.B.): records period of manufacture of exterior lip-notched pottery and Fisher influence.

M-1939. Moccasin Bluff site

Quercus bicolor, interior of $\log$ or twig, Pit 49. Comment (R.B.): mixed sample dates feature, not artifact types.

\section{M-1940. Moccasin Bluff site}

$800 \pm 110$

Celtis occidentalis, Quercus alba, Acer, Carya, Castenea dentato, Quercus bicolor, and Platanus occidentalis from Pit 62, Level 3, Trench C. Exterior mainly $1 / 8$ in. bark, some interior. Comment (R.B.): dates Late Woodland occupation.

\section{M-1941. Moccasin Bluff site}

Platanus occidentalis from Pit 15, Level 5. Interior of 6 in. $\operatorname{limb}$ or trunk. Comment (R.B.): mixed sample dates major occupation with exterior lip-notched pottery.

General Comment (R.B.): 3 occupations indicated: (a) ca. A.D. 1050 with cord-marked, exterior lip-folded pottery like Spring Creek and Fisher, (b) continuation of previous with collared vessels, (c) ca. A.D. 1600 Oneotainfluenced occupation. 


\section{M-1951. Loftin site, Missouri}

Charcoal from Loftin site (23 SN 42) (36 $36^{\circ} \mathrm{N}$ Lat, $93^{\circ} 28^{\prime} \mathrm{W}$ Long), Stone Co., Missouri. Sample from lined pit at Point 4, House 4. Unclassified Mississippian site with strong Caddoan overtones. Coll. 1968 by D. R. Henning; subm. by W. R. Wood. Comment (W.R.W.): this date in Mississippian or Caddoan variant in SW Missouri appears valid. Previous dates (unpubl.) from same site are GXO-676: A.D. $1220 \pm 150$, and GXO-748: A.D. $360 \pm 70$.

\section{Turner-Snodgrass site series, Missouri}

Charred and burned bark, corn, and cane from Turner-Snodgrass site $\left(36^{\circ} 33^{\prime} \mathrm{N}\right.$ Lat, $90^{\circ} 33^{\prime} \mathrm{W}$ Long), Butler Co., Missouri. Middle Mississippian site, should date occupation. Coll. 1966 and subm. by J. E. Price, Univ. of Michigan.

\section{M-1957. Sample RC-1}

Burned bark, Structure 2, bin floor, $23 \mathrm{~N}$ 2.5E, D.D. $6.0 \mathrm{ft}$. Should date structure and corn that it contained.

\section{M-1958. Sample RC-2}

Charred corn, Structure 2, bin floor. Sample from corn bin D.D. $5.8 \mathrm{ft}$. Should date structure and corn.

\section{M-1959. Sample RC-3}

Burned wood from Structure 4, 60N 35E, D.D. 6.1 ft. Fallen wall posts. Should date structure and occupation.

\section{M-1960. Sample RC-4}

Burned bark, Structure 4, 67N 41E, D.D. 9.2 ft. Should date structure and occupation.

\section{M-1961. Sample RC-5}

$810 \pm 110$

Charred post, Structure 6, $19.6 \mathrm{~N} 72.4 \mathrm{E}$, D.D. $6.5 \mathrm{ft}$. Should date structure and occupation.

\section{M-1962. Sample RC-6}

$$
560 \pm 100
$$

Burned wood, Structure 6, 22.4 N 72.6E, no D.D., F.S. 93. Should date structure and occupation.

\section{M-1963. Sample RC-7}

$$
560 \pm 100
$$

Burned cane, Structure 8, 43N 19E, D.D. 6.2 ft. Should date structure and occupation. 


\section{M-1964. Sample RC-8}

Burned rafter, Structure 8, 53N 12E, D.D. 6.9. Should date structure and occupation.

General Comment (J.E.P.): 6 dates appear valid in dating this phase. They range considerably, but are close enough to confirm suspicions about age of site.

\section{M-1965. Incinerator Village site, Ohio}

\section{A.D. 1310}

$640 \pm 100$

Charcoal from Incinerator Village site $\left(39^{\circ} 43^{\prime} \mathrm{N}\right.$ Lat, $84^{\circ} 14^{\prime} \mathrm{W}$ Long), Vance Farm, Montgomery Co., Ohio. Sample made up of small pieces of charcoal from 6 or 8 of 20 refuse pits excavated. Site designated as Incinerator component of Anderson focus of Fort Ancient aspect. Coll. 1964 to 1966 and subm. by J. C. Allman, Dayton, Ohio. Comment (J.C.A.): only other Anderson focus site that has been dated is Erp site $\mathrm{N}$ of here near Pleasant Hill: M-1086, A.D. 1435 to 1475 (Radiocarbon, 1963 , v. 5, p. 230). Considering plus and minus factors, dates match very closely otherwise. This date seems to agree with Fort Ancient dates in general.

\section{M-1967. Bowling Stone Mound, Missouri}

$1560 \pm 140$

Charred nutshells, principally walnut, from Bowling Stone Mound (37 $37^{\prime} 01^{\prime \prime} \mathrm{N}$ Lat, $93^{\circ} 39^{\prime} 26^{\prime \prime} \mathrm{W}$ Long), Cedar Co., Missouri. Sample from Sqs. $50 \mathrm{NW} 50$ and $60 \mathrm{NW} 50$, Woodland burial mound (rock and earth fill), containing limestone-tempered pottery of as yet uncertain affiliation. Coll. 1965 and subm. by W. R. Wood. Comment (W.R.W.): date determination appears to be somewhat early, although mound yielded only limestone-tempered pottery. Rarity of dated sites in SW Missouri, and poorly known cultural sequence make an appraisal difficult.

\section{M-1969. Kram Farm site, Missouri}

$$
960 \pm 110
$$

Wood post from Kram Farm site (23 SL 78) (38 $48^{\prime} \mathrm{N}$ Lat, $90^{\circ} 10^{\prime}$ W Long), Missouri. Sample from House I (crematory or charnel house), Feature A (post pit), Post 2, assoc. with few scraps of shell-tempered pottery, some clay- or grog-tempered pottery (Korando Ware?) in wall trench. Coll. 1959 by D. R. Henning and R. E. Pangborn; subm. by W. R. Wood. Comment (W.R.W.): assoc. clay and grit-tempered pottery apparently of Bluff-Mississippian assoc. Date appears satisfactory.

\section{M-1982. Jancarich site, Michigan}

$$
\begin{aligned}
& 2260 \pm 140 \\
& 310 \text { B.C. }
\end{aligned}
$$

Charcoal from Jancarich site (20 NE 113) (43 $24^{\prime} \mathrm{N}$ Lat, $85^{\circ} 44^{\prime} \mathrm{W}$ Long), T12N, R12W, Newaygo Co., Michigan. Sample is from Feature 
2, TP S6 W2, excavation trench at depth $2.2 \mathrm{ft}$ to $3.0 \mathrm{ft}$. Coll. 1966 and subm. by E. J. Prahl, Univ. of Toledo, Toledo, Ohio. Comment (E.J.P.): too early.

\section{M-1983. Shumaker Mound, Michigan}

$2030 \pm 140$

Charcoal from Shumaker Mound (20 NE 107) $\left(43^{\circ} 25^{\prime} \mathrm{N}\right.$ Lat, $85^{\circ}$ $44^{\prime} \mathrm{W}$ Long), NE $1 / 4$, NE $1 / 4$ Brooks Twp., Newaygo Co., Michigan. Coll. and subm. by E. J. Prahl. Comment (E.J.P.): too early.

\section{M-1985. Palmeteer site, Michigan}

$1960 \pm 140$

Charcoal from Palmeteer site (20 NE 101) $\left(43^{\circ} 24^{\prime} \mathrm{N}\right.$ Lat, $85^{\circ} 44^{\prime}$ W Long), SE 1/4, SW 1/4, Sec. 22, T12N, R12W, Newaygo Co., Michigan. Coll. 1955 by E. Gillis; subm. by E. J. Prahl. Comment (E.J.P.): dates from Jancarich village and nearby Palmeteer and Shumaker mounds, representing period of Hopewellian influence in Lower Muskegon valley, would all seem too early according to postulated time of this activity in area. Cultural material from these 3 sites has been thought to represent stylistic decline assoc. with Late Hopewellian period, as manifested in other areas $\mathrm{S}$ of Muskegon.

\section{M-1984. Carrigan A Mound, Michigan}

$2490 \pm 150$

540 в.C.

Charcoal from Carrigan Mound A (20 NE 106) $\left(43^{\circ} 28^{\prime} \mathrm{N}\right.$ Lat, $83^{\circ}$ $38^{\prime}$ W Long), Newaygo Co., Michigan. Sample from depth $6.3 \mathrm{ft}, 2 \mathrm{ft} S$, $2.5 \mathrm{ft}$ E of Datum A. Coll. 1965 and subm. by E. J. Prahl. Comment (E.J.P.): Carrigan A date from hearth at base of mound agrees with 590 \pm 150 B.C. date of Carrigan B (M-1894), another of group of 5 mounds at confluence of Big and Little Muskegon R. Previously publ. date, A.D. $600 \pm 120$ (M-1759, Radiocarbon, 1968, v. 10, p. 78), dates period of intrusive activity in lower Muskegon valley. Intrusive nature of Carrigan A burial has been corroborated by both cultural and pedologic evidence. Earlier dates for Carrigan A and B line up nicely with dates from Early Woodland level of Schultz site in Saginaw valley.

\section{Yokem Mound site series, Illinois}

Charcoal from Yokem Mounds $\left(39^{\circ} 29^{\prime} 38^{\prime \prime} \mathrm{N}\right.$ Lat, 90 $56^{\prime} 16^{\prime \prime} \mathrm{W}$ Long), Pike Co., Illinois. Coll. 1967 and subm. by Gregory Perino, Tulsa, Oklahoma.

\section{M-1976. Yokem Mound 3}

$760 \pm 110$

Charcoal from intrusive charnel structure found in undisturbed area of potted cemetery. Late Woodland mound with intrusive cremation or crematorium assoc. with 3 long-nosed god masks. Structure of 2 post construction, posts $10 \mathrm{in}$. diam. placed in ground $90 \mathrm{in}$. apart, $4 \mathrm{ft}$ deep. Should date masks. 
M-1994. Yokem Mound 2

Charcoal from burned structure containing 8 Late Woodland burials of which one had 2 triangular side-notched points in rib cage. Should cross-date with charcoal from Mound 3. Structure beneath Mound 2 was 68 in. wide, $14 \mathrm{ft} 4$ in. long, constructed on bluff. Contained 6 skeletons and 2 burial bundles.

General Comment (G.P.): date for M-1976 is very good for maximum date and could be 100 yr later. M-1994 seems to be too late. It is unlikely that similar structure with same exact measurements would have been constructed over $200 \mathrm{yr}$. Compromise of 2 dates ca. A.D. 1300 might be more meaningful. Evidence found in Yokem Mounds 1, 2, and 3 is that 2nd wave of Mississippian-Late Woodland acculturation had been accomplished.

\section{Bridgewater site series, Illinois}

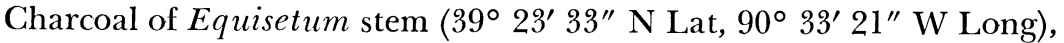
Greene Co., Illinois. Bridgewater is single-component site of the White Hall phase (early Late Woodland). White Hall series sherds were removed from features. Plant remains id. by Shirley S. Maina (n.d.). Samples should date White Hall phase. Coll. 1962 and subm. by S. Struever, Northwestern Univ.

M-1998. Bridgewater site

$$
1470 \pm 130
$$

Feature 2a, charred plant remains from hearth debris in bottom of pit.

M-1999. Bridgewater site

$1050 \pm 200$

Feature 1, portion of charcoal concentration recovered from base of pit.

General Comment (S.S.): M-1998 is within previously established White Hall time span; M-1999 is too late.

\section{Apple Creek site series, Illinois}

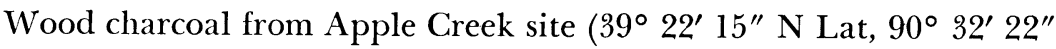
W Long), Greene Co., Illinois. White Hall series sherds in direct assoc. with charcoal. Sample should date White Hall component. Coll. 1963 and subm. by Stuart Struever.

\section{M-1997. Apple Creek site}

$1030 \pm 120$

Feature 451d. Charcoal removed from mass near base of cylindrical pit (Feature 451).

M-2001. Apple Creek site

$1200 \pm 130$

Charcoal from in situ remnant of hearth in base of cylindrical earth oven. 
General Comment (S.S.): M-2001 falls within previously established White Hall time span (M-1262, M-1263, Radiocarbon, 1964, v. 6, p. 4; M-1406; and M-1407, Radiocarbon, 1966, v. 8, p. 266: A.D. 450 to A.D. 750 . M-1997 is too late.

\section{Newbridge site series, Illinois}

Charred plant remains from Newbridge site $\left(39^{\circ} 24^{\prime} 08^{\prime \prime} \mathrm{N}\right.$ Lat, $90^{\circ}$ $33^{\prime} 31^{\prime \prime}$ W Long), Greene Co., Illinois. Newbridge is single-component, White Hall phase (early Late Woodland) site. Coll. 1962 and subm. by Stuart Struever.

\section{M-2000. Newbridge site}

$1290 \pm 130$

Feature 6, charred Chenopodium and Polygonum seeds (id. by Shirley L. Maina, Dept. of Bot., Univ. of Massachusetts). Sample portion of large seed mass recovered from base of pit.

\section{M-2002. Newbridge site}

$1330 \pm 400$

Feature 2, wood charcoal and charred Equisetum stem fragments. Remains removed from base of storage-refuse pit.

General Comment (S.S.): both dates fall within previously established time range for White Hall phase.

\section{Indian Point site series, Ohio}

Charcoal from Indian Point (Lyman) site $\left(41^{\circ} 43^{\prime} 15^{\prime \prime} \mathrm{N}\right.$ Lat, $81^{\circ}$ $11^{\prime} 24^{\prime \prime}$ W Long), LeRoy Twp., Lake Co., Ohio. Site disturbed, but date, if sample is contemporaneous with pottery, will reveal whether or not Late Prehistoric culture was contemporaneous with construction of earth works at site as well as date relatively late (possibly post-contact) Whittlesey site (Mayer-Oakes, 1955; Guthe, 1958). Coll. 1966 and subm. by J. L. Murphy, Nat. Sci. Mus., Cleveland, Ohio.

\section{M-2003. Sample 1}

A.D. 1750

$200 \pm 100$

Sample from unexcavated portion of site along $W$ side of bluff 4 in. below surface and assoc. with both grit and shell-tempered pottery. Comment (J.L.M.): sample contaminated or non-aboriginal. It barely falls within time range expected for Late Whittlesey material with maximum margin of error.

\section{M-2004. Sample 2}

$$
2090 \pm 150
$$

Sample from 4.10 in. below surface. Comment (J.L.M.): substantiates theory that all $\mathrm{N}$ Ohio hilltop fortifications are not Late Prehistoric.

\section{Yankeetown site series, Indiana}

Carbonized wood and burned nut shells from Yankeetown site $\left(37^{\circ}\right.$

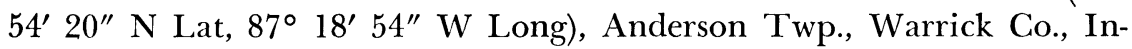
diana (Curry, 1954). Coll. 1967 by J. T. Dorwin; subm. by J. H. Keller, Glenn A. Black Lab. of Archaeol., Indiana Univ. 


\section{M-2007. Yankeetown site, Indiana}

$$
1050 \pm 130
$$

Carbonized wood from Feature 11, bell-shaped pit $3.04 \mathrm{ft}$ deep in Ohio R. alluvial deposit; $1.95 \mathrm{ft}$ top diam.; $4.2 \mathrm{ft}$ at bottom, $1.8 \mathrm{ft}$ deep. Pit contained fish, bird, and mammal bone; worked and unworked stone, large quantities of Yankeetown pottery, and considerable amounts of carbonized wood. Comment (J.H.K.): date is consistent with conclusion that Yankeetown complex was at least coeval with early Mississippian.

\section{M-2008. Yankeetown site, Indiana}

Carbonized wood from Feature 18, heavily fired silt area $8.1 \mathrm{ft}$ deep in Ohio R. alluvial deposit. Assoc. with poorly preserved bone, waterworn sandstone pebbles, thick grit and clay-tempered, cord-marked sherds. Comment (J.H.K.): date suggests early Middle Woodland, and we substantially agree.

\section{M-2009. Yankeetown site, Indiana}

Burned nut shells from Feature 19, basin-shaped area of fired silt $11.3 \mathrm{ft}$ deep in Ohio R. alluvial deposit. Assoc. with fragments of poorly preserved bone, 3 flint flakes, 2 pieces water-worn sandstone. Auger tests immediately below feature produced carbon at $14 \mathrm{ft}$ and fired silt at 19 $\mathrm{ft}$. Burned areas at relatively great depth have been observed in caving Ohio R. bank for years. Comment (J.H.K.): date suggests Early to Middle Woodland transition.

\section{M-2024. Woodpecker site, Missouri}

$475 \pm 100$

Charcoal from Woodpecker site $\left(37^{\circ} 38^{\prime} 41^{\prime \prime}\right.$ N Lat, 93 $44^{\prime} 23^{\prime \prime} \mathrm{W}$ Long), Cedar Co., Missouri. Sample from Sq. 100N 90W, Feature 63 (pit fill) dug into occupational level. Probably single-component, non-ceramic site, perhaps Late Archaic. Coll. 1967 by R. E. Pangborn; subm. by W. R. Wood. Comment (W.R.W.): date is later than suggested by cultural remains.

\section{M-2041. Oak Grove site, Missouri}

$\mathbf{0} \pm \mathbf{1 0 0}$

Charcoal from Oak Grove site $\left(37^{\circ} 33^{\prime} 32^{\prime \prime} \mathrm{N}\right.$ Lat, $93^{\circ} 36^{\prime} 40^{\prime \prime} \mathrm{W}$ Long), Polk Co., Missouri. Sample from occupational zone Sq. 477, 8N $407.5 \mathrm{~W}, 15$ in. below surface. Should date pottery-bearing component. Coll. 1967 by H. T. Ward; subm. by W. R. Wood. Comment (W.R.W.): result not in accord with field data.

\section{M-2049. Daines Mound II site, Ohio}

Charcoal from Daines Mound II site ( $34^{\circ} 18^{\prime} 52^{\prime \prime} \mathrm{N}$ Lat, $82^{\circ} 06^{\prime} 25^{\prime \prime}$ W Long), Athens, Ohio. Carbon from base of mound $7 \mathrm{ft}$ high in initial $\mathrm{N}-\mathrm{S}$ trench, $25 \mathrm{ft} \mathrm{S}$ of edge of mound. Date will be lst for occurrence of Adena corn. Artifacts sparse, but mound is probably Late Adena. Coll. 
and subm. by J. L. Murphy. Comment (J.L.M.): fits known range of Adena culture, and is of particular significance because of occurrence in mound of an ear of Tropical Dent corn (id. by H. C. Cutler, Misssouri Bot. Gardens), 1st definite evidence of Adena corn, and I believe oldest known occurrence of corn in E North America.

\section{M-2055. Naomikong Point site, Michigan \\ A.D. 430}

Charred material scraped from interior of potsherds from Naomikong Point site $\left(45^{\circ} 30^{\prime} \mathrm{N}\right.$ Lat, $84^{\circ} 52^{\prime} \mathrm{W}$ Long), Chippewa Co., Michigan. Scrapings from pseudo-scallop shell vessel found in midden Level 1 of Excavation 525 E 525. Coll. 1967 and subm. by D. E. Janzen, Mus. of Anthropol., Univ. of Michigan. Comment (D.E.J.): since Naomikong Point is atypical Laurel (because of its size), Late Middle Woodland date of A.D. 430 is fine.

\section{M-2069. Fairport Harbor Village site, Ohio}

A.D. 1770

$180 \pm 100$

Charcoal from Fairport Harbor Village site $\left(41^{\circ} 44^{\prime} 47^{\prime \prime} \mathrm{N}\right.$ Lat, $81^{\circ}$ $16^{\prime} 10^{\prime \prime}$ W Long), Lake Co., Ohio. Sample from Trench I. Date should substantiate or disprove Fitting's theory that Fairport site is relatively early in Whittlesey phase (Morgan and Ellis, 1943; Fitting, 1964). Coll. 1966 and subm. by J. L. Murphy. Comment (J.L.M.): site was used for dump, and bad sample is not surprising.

\section{Summer Island site series, Michigan}

Wood charcoal and charred bone from Summer Island site $\left(45^{\circ} 34^{\prime}\right.$ $30^{\prime \prime}$ N Lat, $86^{\circ} 37^{\prime}$ W Long), Delta Co., Michigan. Coll. 1967 and subm. by D. S. Brose.

\section{M-1995. Summer Island site}

$1700 \pm 140$

Charcoal from sand ridge $100 \mathrm{ft} \mathrm{W}$ of shore. Material from refuse pit filled with large, burned limestone and igneous rock fragments, faunal remains, and broken ceramics. Pit assoc. with large midden at this level. Ceramics found in fire-pit: grit-tempered, dentate sherds which seem to relate to Laurel occupation.

\section{M-2070. Summer Island site}

Wood charcoal and charred bone from pit in sand ridge $\mathrm{W}$ of Summer Harbor. Pit is in sub-Mississippian level sands outside midden containing charcoal, 1 poor bifacial blank, much burned rock, and several fragments of mussel shell assoc. with Oneota component.

\section{M-2071. Summer Island site}

Wood charcoal from post molds of double-walled (?) oval structure containing refuse pit with thin cord-marked and sandy incised ceramics. To $\mathrm{N}$ of main occupation of Middle Woodland site: Area $\mathrm{B}$, as part of Oneota component. 


\section{M-2072. Summer Island site

Charcoal of small twigs and branches of cedar from sand ridge $\mathrm{W}$ of Summer Harbor. Pit originating in midden at depth of .65 ft. Charcoal assoc. with $5 \mathrm{~kg}$ fire-cracked rock, 1 unifacial scraper (preform), much burned fish and mammal bone, and Oneota pottery.

\section{M-2073. Summer Island site}

$1880 \pm 280$

Wood charcoal of small twigs of $\mathbf{E}$ cedar in hearth in dense, sandy layer at elev. ca. $596 \mathrm{ft}$. Sample from midden floor from concentration of charcoal, ash and potsherds (plain surface, grit-tempered, dentate stamped). Assoc. fish bone. Ceramics quite Laurel-like. May date A.D. 100 to 400 , assoc. with Laurel occupation.

\section{M-2074. Summer Island site}

$$
1790 \pm 130
$$

\section{A.D. 160}

Charcoal of small branches of aspen and cedar. Fire pit (in N structure, Area C, originates in midden layer and cuts into sterile sands underlying site. Sample assoc. with fish bone, 1 white chert bifacial blade, and grit-tempered, punctate sherds which look like Mason's (Mason, 1966) "Becker Punctate" (A.D. 170). Assoc. with Laurel occupation.

\section{M-2014. Summer Island site}

Charred bones of mature Cervus canadensis canadensis and Ursus americanus from isolated pit below humus along $\mathrm{N}$ wall of excavation unit $500 \mathrm{E} 500$ at point $505 \mathrm{E} 553,1.3 \mathrm{ft}$ deep from surface or $595.7 \mathrm{ft}$ above mean tide. Bones intimately assoc. with body and rim sherds of shell- and grit-tempered vessels tentatively id. as Grand River Plain and Lake Winnebago Trailed (Hall, 1962), as well as Late Woodland ceramics similar to Quimby's (1967) Dumaw Creek in protohistoric component.

General Comment (D.S.B.): M-2073, M-2074, and M-1995 date Middle Woodland occupation in complete agreement with similar materials from Wisconsin (Mason, 1966) and Ontario (Johnston, 1968; Wright, 1967). M-2070, M-2071, and M-2072 pertain to features assoc. with an Upper Mississippian ceramic complex. M-2071 and M-2072 agree with similar Oneota materials from Wisconsin (Hall, 1962; Mason, 1966). $\mathrm{M}-2070$ is from a feature of this component containing large amounts of mussel shell, presumably coll. from gravel bar to NW of site. Waters of this area contain high $\mathrm{CaCO}_{2}$ content (Ayers, 1961) dissolved from Middle Silurian Limestone series, and this may account for unreasonably old date. The $\mathrm{pH}$ of this feature was 8.5 higher than in surrounding soils. M-2014 is gratifying in light of est. date based upon French trade goods, A.D. 1625 to A.D. 1675 (Quimby, 1966). 


\section{Sheep Rock Shelter series, Pennsylvania \\ Northeastern United States}

Charcoal from Sheep Rock Shelter $\left(78^{\circ} 00^{\prime} \mathrm{N}\right.$ Lat, $40^{\circ} 15^{\prime} \mathrm{W}$ Long), Huntingdon, Pennsylvania. Coll. and subm. by J. W. Michels, Pennsylvania State Univ.

\section{M-2081. Sheep Rock Shelter}

A.D. 1870

$80 \pm 100$

W 15, S 05, level 66 to 72 in. Middle Woodland. Comment (J.W.M.): date is apparently derived from large pit, presumably of Susquehannock origin, which penetrates through ash lens from above. To accommodate this interpretation 2 sigmas would be required. Another possibility is historic occupation which is known to have occurred. A.D. 1870 is not surprising.

\section{M-2082. Sheep Rock Shelter}

$1630 \pm 140$

E 20, S 05 , level 70 to 84 in. Early Woodland. Comment (J.W.M.): date is in line with corroborating evidence.

\section{M-2083. Sheep Rock Shelter}

$1890 \pm 140$

E 20, S 00, level 72 in. Early Woodland. Comment (J.W.M.): date is entirely in line and is supported by Sample M-2082.

\section{M-2084. Sheep Rock Shelter}

A.D. 1490

$460 \pm 100$

E 00, S 15, level 78 to 14 in. Early Woodland. Comment (J.W.M.): Middle Woodland date satisfactorily fits Early-Middle Woodland expectations.

\section{M-2085. Sheep Rock Shelter}

E 25, S 15, level 79 in. Early Woodland. Comment (J.W.M.): date concurs with ceramic inferences.

\section{M-2086. Sheep Rock Shelter}

$500 \pm 100$

E 45, S 15, level 95 to 96 in. Early Woodland. Comment (J.W.M.): provenience of this sample and assoc. deposit was in doubt though stratigraphy suggested Late Woodland. Date clarifies chronometric provenience of deposit.

General Comment (J.W.M.): over-all evaluation of samples indicates rather good agreement between expected and observed results. Only $\mathrm{M}-208 \mathrm{I}$ is clearly out of line, a result which was anticipated and is explained by presence of a large intrusive deposit dating from more recent occupation.

Lower Mississippi Valley and Southeast U.S.

\section{M-1358. Barton Ranch site, Arkansas}

$650 \pm 110$

Charred red oak from Barton Ranch site (35० 22' $30^{\prime \prime}$ N Lat, $90^{\circ} 23^{\prime}$ $40^{\prime \prime}$ W Long), Crittenden Co., Arkansas. Carbon of charred house posts 
in subfloor of house pattern $4 \mathrm{ft}$ deep from present ground surface. House floor $2 \mathrm{ft}$ deep when originally excavated by Indians. Coll. 1961 and subm. by Gregory Perino. Comment (G.P.): date seems a little early, for artifacts from site are regarded as typologically later. As a rule, St. Francis sites like Barton Ranch are later than A.D. 1300. House floor sample was taken from also had large sherd of Manley Punctate ware, one of major types at Banks site.

\section{Obion site series, Tennessee}

Wood charcoal from Obion site (16 HY 14) (36 24' $15^{\prime \prime} \mathrm{N}$ Lat, $88^{\circ}$ 23' W Long), Henry Co., Tennessee. Coll. 1967 and subm. by E. E. Baldwin, Dept. of Anthropol., Western Michigan Univ.

\section{M-1953. Specimen 1}

A.D. 1040

$910 \pm 110$

Wood charcoal from midden underlying lst constructional phase of largest mound (6) on site. Should date early (pre-mound) occupation of this Mississippian site (Baldwin, 1967).

\section{M-1954 and M-1956. Specimens 2 and 4$$
\text { A.D. } 1040
$$

$$
\begin{aligned}
& 970 \pm 250 \\
& \text { A.D. } 980 \\
& 910 \mathrm{~N}
\end{aligned}
$$

Wood charcoal from floor $5 \mathrm{ft} 9$ in. below present summit of Mound 6 , and $1 \mathrm{ft} 6 \mathrm{in}$. above Phase $\mathrm{C}$ of construction. Should date middle period of mound "Summit C Times."

\section{M-1955. Specimen 3}

A.D. 990

$960 \pm 150$

Wood charcoal from midden underlying 1st constructional phase of Mound 6. Date should be same as Specimen 1.

General Comment (E.E.B.): M-1953, M-1955: dates are very acceptable for early occupation. M-1954, M-1956: somewhat too early, but in view of large lab. error, dates should not be viewed as disruptive of highly consistent sub-mound dates.

\section{Mexico, Central, and South America}

\section{Cueva Blanca site series, Mexico}

Charcoal from Cueva Blanca site ( $16^{\circ} 57^{\prime} \mathrm{N}$ Lat, $96^{\circ} 20^{\prime} \mathrm{W}$ Long), Oaxaca, Mexico (Flannery et al., 1967). Coll. 1966 and subm. by K. V. Flannery, Univ. of Michigan.

\section{M-2091. Sample OC-30, E9, Zone A}

$$
1330 \pm 130
$$

Zone A dates to Monte Alban V period, Post-Classic, and should have absolute date ca. A.D. 1300 to 1500 . Comment (K.V.F): too early.

\section{M-2092. Sample OC-30, E13, Zone D}

Should date to pre-ceramic Coxcatlan phase, ca. 3000 to 4000 B.C. Comment (K.V.F.): not bad. 
M-2093. Sample OC-30, D8, Zone E

$10,050 \pm 350$ expected.

\section{M-2094. Sample OC-30, I13, Zone E}

$11,000 \pm 400$ 9050 B.c.

Sample from Feature 15, shallow hearth in stratigraphic Zone E, pre-ceramic living floor. Comment (K.V.F.): earlier than expected. Assoc. fauna is all "Recent," and does not include extinct Pleistocene forms.

\section{Guila Naquitz Cave site series, Mexico}

Charcoal from Guila Naquitz Cave site $\left(16^{\circ} 57^{\prime} \mathrm{N}\right.$ Lat, $96^{\circ} 20^{\prime} \mathrm{W}$ Long), Oaxaca, Mexico (Flannery et al., 1967). Coll. 1966 and subm. by K. V. Flannery.

\section{M-2095. Sample OC-43, I7, Feature 7}

A.D. 1710

$240 \pm 100$

Feature 7 was large maguey-roasting pit dating to Post-Classic period. Should date ca. A.D. 1300 to 1500 . Comment (K.V.F.): not bad considering standard deviation.

M-2096. Sample OC-43, GH, Zone A

$1330 \pm 130$

Monte Alban III-B-IV period, presumably A.D. 600 to 900. Comment (K.V.F.): good.

M-2097. Sample OC-43, D10, Zone C

$9400 \pm 300$

Pre-ceramic living floor, previously dated to 6000 to 7000 B. chron, unpubl.). Comment (K.V.F.): perfect.

\section{M-2098. Sample OC-43, D10, Zone D}

$4300 \pm 180$

Pre-ceramic living floor, previously dated to 7000 to 8000 B.c. (Geochron, unpubl.). Comment (K.V.F.): too young.

\section{M-2099. Sample OC-43, E5, Zone D}

$10,700 \pm 350$

Pre-ceramic living floor, previously chron, unpubl.). Comment (K.V.F.): earlier than expected, but not bad.

M-2100. Sample OC-43, F9, Zone C

$5980 \pm 220$ chron, unpubl.). Comment (K.V.F.): too young.

\section{M-2101. Sample OC-43, F8, Zone E}

$6300 \pm 220$

4350 B.c.

Pre-ceramic living floor presumed to date before 7000 B.c. Comment (K.V.F.): too young. 


\section{Hierve el Agua site series, Mexico}

Charcoal from Hierve el Agua site ( $16^{\circ} 54^{\prime} \mathrm{N}$ Lat, $96^{\circ} 15^{\prime} \mathrm{W}$ Long), Oaxaca, Mexico. Site consists of 1 pyramid, series of plazas contoured to mountain side, large travertine-rich spring, and series of prehistoric agricultural terraces and irrigation canals "fossilized" by travertine deposition. Coll. 1967 by J. A. Neely; subm. by K. V. Flannery.

M-2105. Test Pit I

$75 \mathrm{~cm}$ deep, Monte Alban III-B(?) ceramics.

M-2106. Test Pit 40

$113 \mathrm{~cm}$ deep, Late Formative-Early Classic ceramics.

\section{M-2107. Test Pit 40}

$175 \mathrm{~cm}$ deep, Late Formative ceramics.

M-2108. Test Pit 40

$190 \mathrm{~cm}$, Formative ceramics.

M-2109. Test Pit 41

$70 \mathrm{~cm}$ deep, Late Formative ceramics. General Comment (K.V.F.): dates are most satisfactory and acceptable.

M-1638. Site 1, Costa de Reyes, Argentina

$1530 \pm 120$

Charcoal from Site 1, Costa de Reyes, Catamarca Province, Argentina. Sample $3 \mathrm{ft} 3$ in. deep dates oldest pottery known in Abauncan Valley in central zone of NW Argentina. Also dates oldest maize yet known in area. Coll. 1964 and subm. by A. R. Gonzales, Mus. de La Plata, La Plata, Argentina. Comment (A.R.G.): date is satisfactory.

\section{Ancon-Las Colinas site series, Peru}

Charcoal and ashes (probably Tillandsia), from Zona del Tanque de Agua at Ancon (11 $55^{\prime} \mathrm{S}$ Lat, $77^{\circ} 10^{\prime} \mathrm{W}$ Long), Peru. Coll. 1961 by Lorenzo Rossello-Truel and Ramiro Matos Merdietta; subm. by Lorenzo Rossello-Truel, Lima, Peru.

M-1949. Ancon-Las Colinas

$2910 \pm 160$

960 B.c.

Charcoal from deepest level $(5.50$ to $5.75 \mathrm{~m})$ of subsidiary Pit A in Trench T3. Deposit rests atop sterile sand, and is stratigraphically below levels containing materials pertaining to Chira-Villa and Haldas styles. This may date oldest ceramics yet found at site (Willey and Corbett, 1954; Lanning, 1960; Matos, 1962; Rossello, 1962).

M-1950. Ancon-Las Colinas

$$
3100 \pm 160
$$$$
1150 \text { B.C. }
$$

Ashes from depth of $4.50 \mathrm{~m}$ in Pit A, Trench T3. Level marks criti- 
cal stratigraphical and typological break in cultural deposit. Ceramic assoc. are material related to zone-red type defined by Willey and Corbett, material beginning thinner and variegated rim forms of Chira-Villa and Haldas styles (Willey and Corbett, 1954; Lanning, 1960, 1961; Matos, 1960, 1962; Rossello, 1962).

General Comment (L.R.T.): date of M-1950 corresponds well to other recently dated pre-ceramic materials at Las Colinas and La Florida. M-1949 seems somewhat too young. Late date on this latter sample might possibly be explained by the fact that charcoal was stored for several years in small cloth bag. M-1950, on the other hand, was placed in an airtight plastic container immediately after collection.

\section{Africa, Europe, Near East, and Asia}

\section{Radziejow Kujawski series, Poland}

Charcoal and charred wheat from Radziejow Kujawski site No. 1

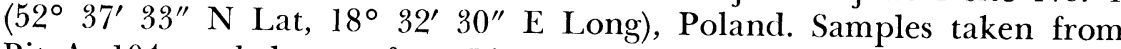
Pit A, $104 \mathrm{~cm}$ below surface. Pit contained only Funnel Beaker sherds; at level of sample an amphora of Funnel Beaker culture was found. Amphora dates site at border of Polish Neolithic Period II and III. Samples will date Funnel Beaker culture and agriculture in Kuyavia. Coll. 1961 by L. Gabalowna; subm. by Sarunas Milisauskas, Univ. of Michigan.

\section{M-1845. Radziejow Kujawski, chareoal, Pit A 2640 B.c.}

\section{M-1845. Radziejow Kujawski, wheat, Pit A}

$4860 \pm 200$ 2910 B.c. General Comment (S.M.): dates agree with expected age of site.

\section{M-1847. Zlotniki site, Poland}

$4810 \pm 200$

Charcoal from Zlotniki site $\left(50^{\circ} 06^{\prime} 00^{\prime \prime} \mathrm{N}\right.$ Lat, $20^{\circ} 16^{\prime} 25^{\prime \prime}$ E Long) Poland. Sample from Pit 51, assoc. with Lengyel and Lustian sherds. Should date Late Lengyel. Coll. 1964 by A. Dzieduszycka-Machnikowa; subm. by Sarunas Milisauskas. Comment (S.M.): date probably would fall within late period of Lengyel culture in S Poland.

\section{M-1848. Przywoz Mound 1, Poland}

$$
1330 \pm 130
$$

Charcoal from Przywoz Mound $1\left(51^{\circ} 08^{\prime} \mathrm{N}\right.$ Lat, $18^{\circ} 43^{\prime} 05^{\prime \prime} \mathrm{E}$ Long), Poland. Sample from fireplace occurring in NW part of mound at depth $2.90 \mathrm{~cm}$ from top. Assoc. with 1 sherd from Roman period. Should date ca. A.D. 180. Coll. 1964 by K. Jazdzewski; subm. by Sarunas Milisauskas. Comment (S.M.): date does not fall within Roman period in Poland. 


\section{Olszanica site series, Poland}

Charcoal from Olszanica site $\left(50^{\circ} 06^{\prime} \mathrm{N}\right.$ Lat, $18^{\circ} 50^{\prime} \mathrm{E}$ Long), Poland. Should be 1st Danubian I dates in S Poland. Coll. 1967 by Gregory Johnson; subm. by Sarunas Milisauskas.

M-1986. Olszanica site, Poland

$6020 \pm 220$

Charcoal from Feature I, 234.25, Danubian (Linear) Pit.

M-2011. Olszanica site, Poland

$6300 \pm 400$

4350 в.c.

Charcoal from Danubian I (Linear) pits. Features 1 (235.56a) and $6(235.20)$.

General Comment (S.M.): most of pottery at Olszanica belongs to Middle and Late phases of Danubian I culture. Dates agree with expected age for site.

\section{Espekaer site series, Denmark}

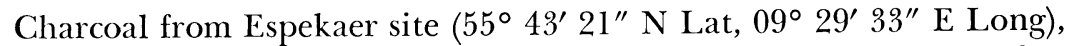
Daugård, Denmark. Samples from conventional "stone heap grave" feature though no direct evidence of burial was present. Unitary feature is man-sized trench filled with stones and boulders assoc. with potsherds, amber, and stone tools of Jutish "Middle Neolithic." Late (?) PittedWare culture site. Est. date 2500 to 2000 B.c. Coll. 1967 by R. M. and E. S. J. Rowlett; subm. by R. M. Rowlett, Univ. of Missouri.

\section{M-2089. Sample I}

$4200 \pm 250$

Bits and pieces of charcoal from cracks around middle and bottom of layers of stone.

\section{M-2090. Sample II}

$3460 \pm 220$

1510 B.C.

Bits and pieces of charcoal from immediately in contact with upper stone layer and from cracks between stones and this layer.

General Comment (R.M.R.): dating determination for Sample I, most protected sample, is probably most applicable. Sample II seemingly includes later, intrusive material.

\section{Munhata series, Israel}

Soil samples from Munhata $\left(32^{\circ} 30^{\prime} 55^{\prime \prime} \mathrm{N}\right.$ Lat, $35^{\circ} 30^{\prime} 25^{\prime \prime} \mathrm{E}$ Long), Israel. Coll. 1965 and subm. by Jean Perrot, Archaeol. Mission, French Consulate Gen., P.O.B. 182, Jerusalem.

\section{M-1792. Munhata, Fireplace 644}

$7370 \pm 400$ 5420 в.c.

Soil (Sample 869) from Fireplace 644, Sq. M 14, Level IV A $.5 \mathrm{~m}$ deep. Should date pre-pottery near 6000 B.c. Comment (J.P.): considerably younger than expected. 
M-1793. Munhata, Trench 631

$9160 \pm 500$

7210 B.C.

Soil (Sample 631) from Trench 631, Sq. L 16, Level IV B or V. Should date near 6500 to 6000 B.c. based on Jericho tests.

\section{Bab edh-Dhra site series, Jordan}

Burnt cloth and wood from Bab edh-Dhra site $\left(31^{\circ} 14^{\prime} 34^{\prime \prime}\right.$ N Lat, $35^{\circ} 31^{\prime} 42^{\prime \prime}$ E Long), Lisan, Jordan. Coll. and subm. by P. V. Lapp, Am. School of Oriental Research, Israel.

\section{M-2036. Sample No. 9}

$4160 \pm 180$

Burnt cloth from floor of entryway to Charnel House A 8, from mass of cloth set afire immediately before final sealing. Ceramic comparative typology including dated Egyptian links suggest date in 25th century B.c. Charnel house contained heaps of disarticulated bones mixed with pots and few copper weapons. Cloth first appeared $<5 \mathrm{~cm}$ deep. Sample ca. $50 \mathrm{~cm}$ deep.

\section{M-2037. Sample No. 10}

$4350 \pm 180$ Conditions as in A 8 , except typology tury B.C.

General Comment (P.V.L.): in general dates provided are satisfactory, and I would tend to keep sequence so far as suggested by preliminary typological study, and say roughly 24th century B.C. for M-3036 and 23rd century B.C. for M-2037. It is possible that more detailed typological study might reverse sequence.

\section{Ishigami-Bokuden Shell Mound series, Japan}

Charcoal from Ishigami-Bokuden Shell Mound $\left(35^{\circ} 50^{\prime} \mathrm{N}\right.$ Lat, $139^{\circ}$ $45^{\prime}$ E Long), Kawaguchi City, Saitama Pref., Japan. Should date from late to latest Jomon period. Coll. 1965 by Masaru Aso; subm. by J. E. Kidder, Internatl. Christian Univ., 1500 Osawa, Mitakashi, Tokyo, Japan.

\section{M-1861. Ishigami-Bokuden Shell Mound, $\quad 3110 \pm 190$ $105 \mathrm{~cm}$ deep \\ 2160 B.c.}

Charcoal from Level 3, pure shell layer, $105 \mathrm{~cm}$ deep. Assoc. with Angyo IIIa pottery of early Latest Jomon period.

\section{M-1862. Ishigami-Bokuden Shell Mound, $\quad 3190 \pm 160$ $160 \mathrm{~cm}$ deep 1240 B.c.}

Charcoal from fireplace of Horinouchi type pit house $160 \mathrm{~cm}$ deep in Late Jomon period.

General Comment (J.E.K.): dates are satisfactory, but would have prefered M-1862 to be $200 \mathrm{yr}$ earlier. Horinouchi may be younger than considered. 
Date lists:
Michigan VIII
Michigan IX
Crane and Griffin, 1963
Michigan XI
Crane and Griffin, 1964
Michigan XII
Crane and Griffin, 1966
Crane and Griffin, 1968

Ayers, J. C. (ed.), 1961, Proc. of the Great Lakes Research Inst., Univ. of Mich., no. 7. Baldwin, E. E., 1967, The Obion site: An early Mississippian center in Western Tennessee: unpub. Ph.D. thesis, Harvard Univ.

Crane, H. R., 1961, The $\mathrm{CO}_{2}-\mathrm{CS}_{2}$ Geiger counter: Rev. Sci. Instruments, v. 32, p. 953. 1963. University of Michigan radiocarbon dates VIII: Radiocarbon, v. 5, p. $228-253$.

p. $1-24$. p. $256-285$.

1964, University of Michigan radiocarbon dates IX: Radiocarbon, v. 6,

1966, University of Michigan radiocarbon dates XI: Radiocarbon, v. 8, 1968, University of Michigan radiocarbon dates XII: Radiocarbon, v. 10, p. $61-114$.

Curry, H. J., 1954, Archaeological notes on Warrick Co., Ind. Hist. Bur., Indianapolis. Fitting, J. E., 1964, Ceramic relationships of four Late Woodland sites in northern Ohio: Wisconsin Archeologist, v. 45, no. 4, p. 160-174.

Flannery, K. V., Kirkby, A. V. T., Kirkby, M. J., and Williams, A. W., Jr., 1967, Farming systems and political growth in ancient Oaxaca: Science, v. 158, no. 3800, p. $445-454$.

Guthe, A. K., 1958, The Late Prehistoric occupation in southwestern New York: an interpretive analysis: New York State Archaeol. Assoc. Trans., v. xiv, no. 1, p. 59.

Hall, R., 1962, Carcajou Point: Univ. of Wisconsin Press, Madison, Wisconsin.

Hough, J. L., 1955, Lake Chippewa, a low stage of Lake Michigan indicated by bottom sediments: Geol. Soc. America Bull., v. 66, p. 957-968.

Johnston, R. B., 1968, The archaeology of the Serpent Mound site: Royal Ontario Mus., Univ. of Toronto Occ. Paper no. 10.

Lanning, E. P., 1960, Ceramica antiqua de la Costa Peruana: nuevos descubrimientos, 2nd ed., Tawantisuyu K'usky Paqarichisqa, Berkeley, California.

1961, Ceramica pintada Pre-Chaovin de la Costa Central del Peru: Rev. Mus. Nacional, tomo xxx, p. 79-84.

Maina, Shirley L., n.d., Ethnobotany of Newbridge and Bridgewater, two prehistoric sites in the lower Illinois River Valley: unpub. ms.

Mason, R. J., 1966, Two stratified sites on the Door Peninsula of Wisconsin: Anthropol. Papers, Mus. of Anthropol., Univ. of Michigan, no. 26.

Matos, R. M., 1960, Projecto de investigaciones arqueologicas en Ancon: Mimeo. Paper, Univ. Mayor de San Marcos, p. 20.

1962, La ceramica temprana de Ancon y sus problemas: Ph.D. thesis, Univ. Mayor de San Marcos, Lima.

Mayer-Oakes, W. J., 1966, Prehistory of the Upper Ohio Valley: Carnegie Mus. Ann., v. 34, p. 204

Morgan, R. G. and Ellis, H. H., 1943, The Fairport Harbor Village site: Ohio Archaeol. and Hist. Quart., v. 52, no. 1, p. 1-62.

Quimby, G. I., 1966, The Dumaw Creek site: Fieldiana, Anthropol., v. 56, no. 1.

Rossello, L. T., 1962, Investigaciones arqueologicas sobre los estelos tempranos de Ancon: Conf. sustentada en el Mus. de la Univ. de San Marcos, recorded on tape.

Swartz, B. K., Jr. (ed.), 1966, First annual Ball State Univ. Summer Field School Archacol. repts.

Tijmens, W. T., 1965, From an ancient desert relict: Nat. Hist., v. lxxvi, no. 4, p. 3637. 52 , p. $22-23$

1966, Welwitschia bainesii (Hook f.) Carr.: Jour. Bot. Soc. of S. Africa, pt. 52, p. 22-23.
illey, G. R. and Corbett, J. M., 1954, Early Ancon and Supe culture: New York, Columbia Univ. Press.

Wright, J. V., 1967, The Laurel tradition: Natl. Mus. Canada, Bull. 217, Ottawa. 